\title{
Implementation Strategy Research on Team Graduation Design of Automobile Specialties Based on Engineering Project
}

\author{
Peijiang Chen * \\ School of Automobile, Linyi University, Shandong, 276000, China \\ chenpeijiang@163.com
}

Keywords: Team graduation design; Engineering Project; Automobile Specialties; Implementation Strategy

\begin{abstract}
Aiming at the practicality, comprehensiveness, innovativeness and collectivity of the graduation design of automobile and other engineering specialties. On the background of real automobile engineering projects, a working model under the leading of item is established, the teaching reform practice of team graduation design is implemented. The quality management of whole process is strengthened, the subjective initiative and collaborative innovation spirit of students are fully developed. In the real project and engineering environment, the teams of graduation design are set up, then, there are division of labor and coordination among members. The team graduation design can effectively improve graduation teaching quality, broaden students' horizons, active thinking, strengthen innovation awareness, group spirit and practical ability and cultivate highly quality applied talents.
\end{abstract}

\section{Introduction}

Graduation design is an important part of undergraduate training program and it is an important reflection of combination of education, productive labor and social practice. Graduation design is an important practical link in cultivating the creative ability, practical ability and preliminary scientific research ability of students [1]. It plays an irreplaceable role in cultivating the scientific spirit of undergraduates, training basic scientific research, improving comprehensive practical ability and quality. The graduation design is an important indicator to reflect the talent training quality for undergraduates.

But through the research, the project team finds that, the situation of undergraduate's graduation design is not optimistic in recent years and there is a problem of quality reduction [2]. T he causes of this problem are various, such as: less attention of students, great pressure from employment and becoming postgraduate, inadequate investment in energy; inappropriate topics from teachers, lack of practical engineering background; less standardized process management, relaxed evaluation, discordant academic achievement, and so on.

As the specialist elite college of applied talents training, Linyi University is committed to developing high-quality talents, emphasizing the practical ability of students. Correspondingly, as a very important practical teaching link, the form and content of graduation design also need reform.

Based on the guidance of engineering project, this project implements team cooperation for graduation design. A various of researches about the contents and forms of graduation design are carried out, including design topics, teacher guide, design pattern, process management, assessment, and so on. The study and practice are to solve the existing problems, improve the teaching quality of graduation design, guarantee undergraduate teaching effectiveness and train high quality practical talents.

\section{Research status of undergraduate graduation design}

In order to improve the teaching quality of graduation design for undergraduates, the existed patterns of graduation design at home and abroad are analyzed, and their advanced experience are summarized. 
Implementation status abroad. The forms of graduation design in American universities are flexible. They not only pay attention to train the students' hard-ability of professional knowledge, but also put more focus on training soft ability of teamwork and communication. For example, the Engineering College of Texas A \& M University particularly stresses that the instructors should help students form research group, organize team regularly carry out technical exchanges and cultivate the students' cooperative consciousness [3].

The higher education in the United Kingdom focuses on the academic level and quality [4]. The graduation design is an important judgment for undergraduate college career. It has a significant impact on the academic achievement, awarding degree, employers' choice, the selection of postgraduate tutor. Therefore, the evaluation of graduation design in British is very important the methods are continuously updated, such as double evaluation, and so on.

The universities in Germany pay more attention to training students' vocational ability. There are different forms of cooperation with enterprises, including the company offering graduation design jobs to students. For example, in Munich University of Applied Sciences, more than $80 \%$ of students choose to complete graduation thesis or design in enterprises, and they solve the practical problems and make them as thesis topics [5]. In the completion of graduation design, the students can get the tutorship from relevant enterprise experts in certain fields, in addition to the guidance from university tutors.

The undergraduate education in Japan's Universities attach great importance to the graduation design. The students use an entire year to complete the design thesis. Then, they can receive more standardized scientific training, and their practical working ability are improved greatly. The topics of graduation design are real projects which come from scientific research projects funded by the state or the technical development projects appointed by companies. In order to strengthen the assessment, there are two supplementary examinations in the first and second semesters of the fourth grade and several usual research assessments.

Through the analysis of implementation forms of undergraduate graduation design in the developed countries, they attach importance to graduation design. Most of topics come from the real engineering projects. The universities emphasis on teamwork, strengthen the cooperation between school and enterprise, pay more attention to process management and evaluate strictly.

Implementation status in China. As the higher education in China has completed the transition from elite education stage to the popular stage, it is necessary to train applied talents for the development of higher education and social economy. The high quality practical talent is a kind of versatile person between academic research talent and skill practical talent. Correspondingly, domestic universities have also made a number of innovations studies about graduation design.

The power system and automation major of Shenyang Institute of Engineering proposes a graduation model based on the item-guide [6]. Chongqing Jiaotong University takes advantage of the education idea of large engineering and puts forward the engineering graduation design mode based on project team [7]. Changzhou Institute of Technology use combination involving production, teaching and research to carry out graduation design [8]. National University of Defense Technology takes the model of team design project to guide graduation design for undergraduates [9].

These studies have explored the modes and strategies of graduation design, but there are some defects in terms of the combination of engineering project guidance and team collaboration.

\section{Implementation strategies of team graduation design}

Linyi University is an specialist elite college of applied talents training in Shandong province, China, which task is to train high-quality applied talents. To adapt, making the automobile specialties as an example, this project studies the mode and implementation strategies of team graduation design based on engineering items. 
Establish the engineering project-oriented topics selection mode. Choosing the graduation topics appropriately or not is an important prerequisite to ensure the teaching quality of graduation design. Under the premise of topics conforming to the professional training objectives, the proportion of topics from the real engineering projects are increased. The gradation design topics can be the teachers' scientific research projects, enterprises' actual production problems or topics of internship units. The topics should be forward-looking and practical, really combining the theory and practice. It can overcome the gap between the traditional graduation design and and actual practice.

Carry out the model of team graduation design to cultivate students' cooperation sense. Team graduation design refers to dividing a large graduation project into several sub-topics, which are assigned to different students to complete [10]. At the same time, the students should note the link between the total topic and sub-topics. The team has a total instructor, each student has his instructor. In terms of graduation design's topics, all the members jointly develop the research objectives, research contents and overall program. The team leader is responsible for the development of subject program, each student of the team studies a sub-project. In terms of project contents, the team develops technology roadmap and implementation method. In the concrete implementation process, each student is responsible for one part. For the paper writing, the team conceives the overall structure and main content of the graduation thesis, each student completes his essay writing of the sub-topic. In these processes, they discuss, educate, and learn form each other, and constantly improve the writing quality of graduation design.

The thought of team graduation design highlights the important role of graduation design aspect in the talent development. It is conducive to the cultivation of students' comprehensive quality, innovation ability and organizational coordination ability. The students can meet the social development needs of division of social work and cooperation.

Construction engineering environment to cultivate students' application ability. The relevant laboratories open throughout the day, such as Automobile Engineering Training Center, Smart Automobile Innovation Laboratory, and so on. They are made as the technological innovation platform of graduation design for the undergraduate students. These laboratories have good software and hardware resources which can offer advanced experimental conditions and ideal engineering environment. The students complete their graduation design in real project and engineering environment. It can broaden students"' horizons, dig out creativity and develop engineering capabilities.

Cooperate between school and enterprise to guide graduation design. Cooperation between school and enterprise, combination involving production, teaching and research are very important in developing students' comprehensive ability and employment competition ability. Currently, school of automobile of Linyi University has established a long term cooperation mechanism with many companies, such as Shandong Xindayang electric vehicles, Shandong Yuantong automobile trade group, and so on. These units form stable base of graduation design. The companies offer internships, the college includes the production problems into the research projects which are divided into many sub-projects as graduation design topics. The engineering technical personnel of companies are hired as part-time instructors of student graduation design.

The combination involving production, teaching and research guiding graduation design can enable students contact with the actual project and help students cultivate engineering consciousness, social responsibility, pragmatic, rigorous and practical style of study.

Introduce project management system to enhance process management. For the implementation of graduation design, the quality management and monitoring of the whole process is crucial to ensure the teaching quality. The graduation design adopts supervisor responsibility system, the instructor puts forward specific provision and the implementation details of the design schedule, process management, quality standards and other aspects. 
It introduces project management system to monitor the whole process of graduation design. The technology roadmap is as follows:

Topic selection $\rightarrow$ Feasibility research $\rightarrow$ Requirement analysis $\rightarrow$ Proposal presentation $\rightarrow$ Overall design $\rightarrow$ Detail design $\rightarrow$ Development $\rightarrow$ Experiment and verification $\rightarrow$ Thesis writing.

The working process is as follows:

Daily counseling $\rightarrow$ Weekly meetings $\rightarrow$ Mid-term examination $\rightarrow$ Thesis form review $\rightarrow$ Thesis proposal $\rightarrow$ Thesis defense.

These measures can improve the quality of graduation design. From the topic selection, in the design process, the check and guidance are implemented regularly and the seminars are held timely to solve the problems encountered. These methods can provide an institutional guarantee for the completion of graduation design.

Establish graduation design website to share resource. In the website of school of automobile, as the supplementary of graduation design management system of Linyi University, a teaching resources website about graduation design is established. The main contents include graduation design management documents, information bulletins, thesis writing guide, commonly used design manual, outstanding graduation design work, communication online, answering question, and so on. The website can not only share information resources, but also exercise the students' ability to look for materials independently.

\section{Implementation case of team graduation design}

Making the real automobile engineering projects as the themes of graduation design, the teachers with high research ability or extensive practical experience are selected as graduation design instructors by cross-disciplinary, cross-college and cross-school. Taking the undergraduate majors in school of automobile as experimental units, selecting the two automobile specialties, including vehicle engineering and automobile service engineering, as the the implementation focus, the mode of team graduation design is implemented to effectively improve students' practical ability, innovation ability and teamwork ability.

According to the above analysis, in the graduation design of vehicle engineering major, the idea of team graduation design is used. In the selection of subject topics, studying contents and specific design process, there are labor division and cooperation for the team members, which can guarantee the harmonious progress of the research and graduation design. An example of team graduation design is given, as shown in Table 1.

Table 1 An implementation example of team graduation design

\begin{tabular}{llll}
\hline Topic of graduation design & Student & \multicolumn{1}{c}{ Task of graduation design } \\
\hline Main topic & $\begin{array}{l}\text { Design of vechicle } \\
\text { distance } \\
\text { system }\end{array}$ measurement & $\begin{array}{c}\text { Chenglong } \\
\text { Yang }\end{array}$ & $\begin{array}{l}\text { Team leader; design manager; write the total } \\
\text { report of the team graduation design. }\end{array}$ \\
$\begin{array}{l}\text { Total design of vehicle } \\
\text { distance measurement } \\
\text { system based on } \\
\text { binocular stereo vision }\end{array}$ & Yang & $\begin{array}{l}\text { Design the total structure of system, measure the } \\
\text { vehicle distance, analyze the experimental results; } \\
\text { write the thesis of sub-project. }\end{array}$ \\
$\begin{array}{l}\text { Camera calibration } \\
\text { technologies of binocular } \\
\text { stereo vision }\end{array}$ & Aoxiang & $\begin{array}{l}\text { Manufacture the two-dimensional target, calibrate } \\
\text { the camers to get the interal and external } \\
\text { parameters; write the thesis of sub-project. }\end{array}$ \\
$\begin{array}{l}\text { Feature points Extraction } \\
\text { of automobile's rear } \\
\text { licence plate }\end{array}$ & Xin Ge & $\begin{array}{l}\text { Use corner detection to extract automobile's rear } \\
\text { licence plate, comptue the three-dimensional } \\
\text { coordinates; write the thesis of sub-project. }\end{array}$ \\
\hline
\end{tabular}




\section{Conclusions}

From a point of topic selection of automobile engineering project, the engineering environment of graduation design is constructed and the working pattern of standardization process of graduation design is innovated to to meet the training requirements of high-quality application-oriented talents. At the same time, the team teaching model in the graduation design is established which is complemented with the traditional graduation design of individual student. The teachers and students of the team of built cross-disciplinary and cross-school. The student members of the team have division of labor and mutual collaboration. The mode of team graduation design can cultivate the students' practical ability and team collaboration ability.

\section{Acknowledgment}

This work was supported by the Teaching Research Project of Young Teachers of Shandong, China (No. 15SDJ014), the Teaching Reform Project of Linyi University(No. 2014016), and the Teaching Quality Engineering Project of Linyi University in 2014.

\section{References}

[1] X. J. Zhang, L. H. Tang, C. Y. Jia, H. Chen, Based on the Team Graduation Thesis Model to Cultivate Students' Comprehensive Quality, Guangzhou Chemical Industry and Technology. 39(22) (2011) 139-140.

[2] C. X. Wang, X. B. Song, J. C. Lv, X. M. He, T. C. Zhou, Practice of Team-Teaching Model for Undergraduate Thesis of Textile and Dyeing and Finishing Engineering Specialty, Shandong Textile Economy. (4) (2013) 99-101.

[3] Z. L. Ma, Survey and revelation of Undergraduate Design of College of Engineering of Texas A \& M University, USA, Experimental Technology Management. 20(9) (2013) 188-191.

[4] G. P. Zhou, Y. M. Wang, New Exploration of Student Graduation design Evaluation in British University, Comparative Education Review. (S) 2000, 179-184.

[5] J. Sun, Forms, Characteristics and Development Trends of Cooperation between Universities of Applied Sciences and Enterprises in Germany, Comparative Education Review. (2) (2012) 41-45.

[6] Research and Practice of Project-oriented Graduation Design Models of Electric System and Automatism Major, China Electric Power Education. (6) (2009) 161-162.

[7] X. B. He, Y. X. Wen, Exploration of Engineering Graduation Design Models Based on Project Team, Liaoning Education Research. (12) (2008) 62-64.

[8] G. S. Yao, J. X. Chen, The Strengthening of Graduation Design Based on the Combination of Research and Development, Journal of Changzhou Institute of Technology. 19(1) (2006) 86-89.

[9] D. X. Li, Y. H. Meng, J. P. Jiang, C. Z. Fan, W. K. Cheng, Practice and Discussion of the Graduation Projects Based on Group Design Projects, Journal of Higher Education Research. 36(1) (2013) 117-119.

[10] Y. J. Zhang, J. He, F. L. Xiao, Discussion on Graduation Design Mode for Civil Engineering Specialty Based on Team Cooperation, Journal of Hunan University of Technology. 22(3) (2018) 107-109. 